\title{
Comparison of Schirmer and Tear Break Up Time (TBUT) Diagnostic Test of Dry Eye Following Phacoemulsification Cataract Surgery
}

Disty Andryani ${ }^{1 *}$, Petty Purwanita ${ }^{1 *}$, Anang Tribowo ${ }^{1 *}$

${ }^{1}$ Department of Ophthalmology, Faculty of Medicine, Universitas Sriwijaya, Indonesia

*Correspondence author email : distyandryani@gmail.com

\begin{abstract}
Background: Phacoemulsification is a technique of modern cataract surgery with smaller corneal incision than conventional techniques but uses various effects on springs that cause dry eye syndrome (DES). DES is a multifactorial defect of tears and ocular surfaces characterized by eye discomfort. Examination of DES can be done by examining Schirmer 1 and Tear Break Up Time (TBUT).
\end{abstract}

Method: Diagnostic test has been done in order to the accuracy, sensitivity and specificity of the Schirmer test dan TBUT on DES in post operative cataract surgery with phacoemulsification techniques. This study has been conduct Schirmer 1 test and TBUT was done periodically from 1 week, 2 weeks and 1 month after cataract surgery. The data analysis has been done with diagnostic research by SPSS version 20.0 (SPSS, Inc Chicago, Illinois).

Result: 40 study samples of post operative cataract surgery with phacoemulsification technique obtained by female sex with 22 out of samples were (55\%), with an average age of patients between of 60-70 years. The accuracy of Shirmer 1 and TBUT test was 0,425 and the sensitivity value was $39.5 \%$ and also the specificity value was $100 \%$.

Conclusion: Schirmer 1 test and TBUT in patients of post cataract surgery with phacoemulsification techniques are specific (100\%) but less sensitive $(39,5 \%)$

Keyword: Schirmer 1, TBUT, Dry Eye Syndrome, Phacoemulsification 


\section{SRIWIJAYA \\ JOURNALOFOPHTHALMOLOGY}

अग्र०

\section{Introduction}

Dry eye syndrome (DES) is a multifactorial disorder of tears and ocular surfaces characterized by discomfort in the eye associated with decreased tear production and abnormally rapid tear evaporation abnormalities. ${ }^{1,2}$

The prevalence of DES increases with age, regarding about $5 \%$ of the adult population during the fourth decade of life, increasing to $10-15 \%$ in adults over the age of 65 years. The incidence increases with age of 10\% from the age group of 30-60 years and 15\% of the age group of 65 years. The prevalence of DES in the population above 50 years is around 5-35\%. Based on research in America, an estimated 3.23 million women and 1.68 million men from 4.91 Americans suffer from dry eye syndrome. ${ }^{3-5}$

Dry eye syndrome can be caused by aqueous tear deficiency and due to evaporation. Tears consist of three layers, namely lipids, aqueous, and mucin. The tear layer has a thickness of around 8-9 $\mu \mathrm{m}$. The lipid layer has a thickness of 0.1-0.2 $\mu \mathrm{m}$ and is the outermost layer that serves to prevent evaporation of tears and maintain tear stability. The aqueous in the middle has a thickness of 7-8 $\mu \mathrm{m}$ which is the main component of the tear layer. The aqueous layer contains electrolytes, water and proteins produced by the main lacrimal glands located in the orbit. Besides, the layer of aqueous as an antibacterial and antiviral, it also functions as a nutrient solvent, oxygen provider, and maintain corneal regularity. The posterior part of the tear layer is the $1 \mathrm{~m}$ thick mucin layer containing glycoprotein. The mucin layer acts as a barrier from adhesions or penetration of foreign particles or bacteria to the surface of the eyeball. This mucin layer is produced by the conjunctival goblet glands

Tear secretion especially the aqueous layer is produced by the lacrimal gland. Tear secretion is affected by the nervous system involving a complex functional lacrimal unit. Stimulation from the surface of the eyeball will stimulate lacrimation reflexes. Lacrimation reflexes are important especially as protection of the eyeball. Disorders of tear secretion will cause dry eye syndrome (DES). Some epidemiological studies report aging, diabetes, antihistamine use and eye surgery involving the cornea are risk factors for dry eye syndrome. Cataract surgery aims to produce sharp eyesight, but the symptoms of dry eye syndrome are obtained. Phacoemulsification technique is a modern cataract surgery technique with a corneal incision technique that is smaller than conventional techniques but can cause various effects 


\section{SRIWIJAYA JOURNALOFOPHTHALMOLOGY}

ध्रु०

on the stability of tears due to disruption of the corneal nerve. Both conventional cataract surgery and phacoemulsification, symptoms of dry eye syndrome remain after surgery.

Symptoms such as this cause discomfort in the eyes of patients who are often expressed in patients with dry eye syndrome, this complaint can be in the form of pain in the eye, burning sensation, decreased vision, disruption of activity to affect the quality of life of patients. This occurs due to interference with the tear layer that protects the surface of the eyeball. ${ }^{1-3}$

The examination of dry eye syndrome in the form of subjective and objective examinations. Subjective examinations in the form of the Ocular Surface Disease Index (OSDI) questionnaire, assessment of tear function in quality and quantity can be done by examining the Schirmer I and Tear Break-Up Time (TBUT). Schirmer I examination is carried out to assess the quantity of tear production produced by the lacrimal glands. This examination uses Schirmer filter paper on the lateral third of the lower eyelid for 5 minutes with eyes closed. While the TBUT examination to assess the stability of the tear layer, this examination is carried out using fluorescein strip placed in the conjunctival fornix and performed on a slit lamp with a blue filter, the patient is asked to blink naturally and after the last blink begins measurement of the time of tear film rupture or black spots on the cornea, normally> 10 seconds. ${ }^{1,4-6}$

$\mathrm{Li}$, et al in 2007 reported the highest percentage in patients with symptoms of dry eye syndrome after phacoemulsification with decreased production in tear meniscus, decreased TBUT, decreased Schirmer. A study to examine dry eye syndrome and analyze pathogenic factors in patients after cataract surgery is done by Schirmer and TBUT examination, both tests are used because it is very easy to detect and rarely occurs inflammation. Ram, et al. reported no changes in DES from before and after phacoemulsification in 23 patients when examining TBUT and Schirmer 1 under anesthesia. Cho, et al in 2015, reported that in patients after phacoemulsification cataract surgery for 3 months the OSDI questionnaire was examined for an increase in OSDI score. ${ }^{7-10}$

This research is a descriptive study of 40 post-operative cataract samples conducted with phacoemulsification techniques. This research is expected to be able to help establish diagnostics in postoperative cataract sufferers so that it can prevent complications and will support the results of existing studies. The Ocular Surface Disease Index (OSDI) questionnaire, a Schirmer I and Tear Break Up Time (TBUT) examination was performed in patients with post operative cataracts. 


\section{Methods}

This research is a descriptive study with a diagnostic test design to determine the difference in the incidence of dry eye syndrome in patients who have had cataract operations using phacoemulsification surgery using the Schirmer I test and TBUT in the Eye Special Hospital of South Sumatra Province. This research was conducted at the clinic at the Eye Hospital of South Sumatra Province. The entire period of implementation starts from March to January 2019. The population target was post-operative cataract patients with phacoemulsification operative techniques who came to the Clinic of the Eye Hospital of South Sumatra Province, and agreed to be included in this study. The study sample was all patients with post operative cataract dry eye syndrome with phacoemulsification techniques that met the inclusion criteria.

\section{Results}

General characteristics of respondents are shown in table 1 . The mean of cataract patients was 58.25 years with a range of age 43 to 70 years. The majority of cataract patients are female $(55 \%)$ with the majority of the age range $60-70$ years $(50 \%)$.

Table 1. Baseline Characteristics

\begin{tabular}{|c|c|c|c|}
\hline Variable & & Frequency & Percentage \% \\
\hline & Mean \pm SD & & 338 \\
\hline & Range & & \\
\hline & Median & & \\
\hline \multirow[t]{3}{*}{ Age } & 40-49 years old & 4 & 10,0 \\
\hline & $50-59$ years old & 16 & 40,0 \\
\hline & $60-70$ years old & 20 & 50,0 \\
\hline \multirow[t]{2}{*}{ Gender } & Male & 18 & 45,0 \\
\hline & Female & 22 & 55,0 \\
\hline \multirow[t]{2}{*}{ Address } & Within city & 32 & 80,0 \\
\hline & Out of town & 8 & 20,0 \\
\hline \multirow[t]{6}{*}{ Education } & Elementary School & 10 & 25,0 \\
\hline & & 7 & 175 \\
\hline & Junior High School & 8 & 20,0 \\
\hline & Senior High School & 2 & 5,0 \\
\hline & & 13 & 32,5 \\
\hline & Diploma & & \\
\hline
\end{tabular}




\begin{tabular}{|c|c|c|c|}
\hline & Bachelor & & \\
\hline \multirow[t]{8}{*}{ Occupation } & \multirow[t]{2}{*}{ housewife } & 8 & 20,0 \\
\hline & & 5 & 12,5 \\
\hline & worker & 5 & 12,5 \\
\hline & \multirow[t]{2}{*}{ Farmer } & 4 & 10,0 \\
\hline & & 1 & 2,5 \\
\hline & The trader & 17 & 42,5 \\
\hline & \multicolumn{3}{|c|}{ Government employee } \\
\hline & \multicolumn{3}{|l|}{ Retired } \\
\hline
\end{tabular}

The majority of patients live in cities (80\%), have a final education of 13 people $(32.5 \%)$ and work as retirees $(42.5 \%)$.

Table 2 Characteristics of Relationship between Incision Location Types and Schirmer I and TBUT Examinations

\begin{tabular}{lccc}
\hline \multicolumn{1}{c}{ Variabel } & Sub Temporal & Temporal & p value \\
\hline Schirmer I Preoperative & $13,57 \pm 3,98$ & $15,29 \pm 5,06$ & $0,233^{*}$ \\
- Mean \pm Deviation standard & $8-24$ & $8-27$ & \\
- Range & 14,0 & 15,0 & \\
- Median & & & \\
\hline
\end{tabular}

- Schirmer I Postoperative

\begin{tabular}{|c|c|c|}
\hline Mean \pm SD & $11,00 \pm 3,67$ & $12,18 \pm 5,43$ \\
\hline - Range & $6-18$ & $5-23$ \\
\hline - Median & 10,0 & 11,0 \\
\hline
\end{tabular}

\begin{tabular}{|c|c|c|c|}
\hline \multicolumn{4}{|l|}{ TBUT Preoperative } \\
\hline $\begin{array}{l}\text { - Mean } \pm \text { Deviation Standard } \\
\text { - Range } \\
\text { - Median }\end{array}$ & $\begin{array}{c}9,74 \pm 2,91 \\
3-15 \\
10,0\end{array}$ & $\begin{array}{c}11,53 \pm 3,57 \\
7-20 \\
10,0\end{array}$ & $0,226 * *$ \\
\hline \multicolumn{4}{|l|}{ TBUT Postoperative } \\
\hline $\begin{array}{l}\text { - Mean } \pm \text { Deviation Standard } \\
\text { - Range } \\
\text { - Median }\end{array}$ & $\begin{array}{c}8,87 \pm 2,51 \\
5-14 \\
9,0\end{array}$ & $\begin{array}{c}9,82 \pm 3,25 \\
5-16 \\
10,0\end{array}$ & $0,301 *$ \\
\hline
\end{tabular}

* Independent test $\mathrm{T}, \mathrm{p}=0.05$ 


\section{JOURNAL OF OPHTHALMOLOGY}

\section{SET}

** Mann Whitney Test, $\mathrm{p}=0.05$

With the statistical test results obtained there is no difference in the results between

SchirmerI examination and TBUT before and after phacoemulsification surgery based on the type of incision location $(\mathrm{p}>0.05)$

The majority of vision before surgery was 1/60 (30\%) whereas after surgery the majority of vision were 6/15 and 6/21 20\% respectively. Before surgery Schirmer I values were abnormal in 6 patients (15\%) and increased 1 month after surgery to 15 people $(37.5 \%)$, likewise the TBUT value increased before surgery 34 patients $(85 \%)$ and after surgery to 38 patients $(95 \%)$.

Table 3 Ophthalmological Characteristics of Subjects

\begin{tabular}{ccc}
\hline Variable & Total & Percentage \\
\hline Preoperative Visual Acuity & 12 & 30,0 \\
$\bullet 1 / 60$ & 8 & 20,0 \\
$\bullet 2 / 60$ & 3 & 7,5 \\
$\bullet 3 / 60$ & 6 & 15,0 \\
$\bullet 4 / 60$ & 6 & 15,0 \\
$\bullet 5 / 60$ & 5 & 12,5 \\
$\bullet 6 / 60$ & &
\end{tabular}

Schirmer I Preoperative

- Abnormal

6

15,0

- Normal

TBUT Preoperative

- Abnormal

- Normal

15,0

6

\begin{tabular}{lcc}
\hline Postoperative visual Acuity & 2 & \\
- $6 / 7,5$ & 7 & 5,0 \\
- $6 / 9$ & 7 & 17,5 \\
- $6 / 12$ & 8 & 17,5 \\
- $6 / 15$ & 1 & 20,0 \\
- $6 / 18$ & 8 & 2,5 \\
- $6 / 21$ & 5 & 20,0 \\
- $6 / 30$ & 2 & 12,5 \\
\hline
\end{tabular}




\section{JOURNAL OF OPHTHALMOLOGY}

ज्ञा०

- $6 / 60$

Schirmer I month after surgery

- Abnormal

15

37,5

- Normal

25

62,5

TBUT 1 month after surgery

- Abnormal

38

- Normal

95,0

2

5,0

There was a decrease in the value of Schirmer I and TBUT 1 week after surgery and decreased further 1 month after surgery. In addition, an increase in the value of OSDI before and 1 month after surgery.

Table 4 Ophthalmological Characteristics of Research Subjects based on Schirmer 1, TBUT and OSDI

\begin{tabular}{|c|c|c|c|}
\hline Variable & Schirmer 1 & TBUT & OSDI \\
\hline \multicolumn{4}{|l|}{ Preoperative } \\
\hline - Mean \pm Standar Deviasi & $14,3 \pm 4,49$ & $10,5 \pm 3,29$ & $9,65 \pm 1,37$ \\
\hline - Range & $8-27$ & $3-20$ & $7-12$ \\
\hline - Median & 14,5 & 10,0 & 10,0 \\
\hline \multicolumn{4}{|l|}{1 week after surgery } \\
\hline - Mean \pm Standar Deviasi & $12,8 \pm 4,54$ & $10,2 \pm 3,04$ & Tidak dilakukan \\
\hline & $6-25$ & $4-18$ & Tidak dilakukan \\
\hline - Median & 14,5 & 10,0 & Tidak dilakukan \\
\hline \multicolumn{4}{|l|}{2 weeks after surgery } \\
\hline - Mean \pm Standar Deviasi & $11,93 \pm 4,79$ & $9,38 \pm 2,95$ & Tidak dilakukan \\
\hline $\begin{array}{l}\text { - Range } \\
\text { - Median }\end{array}$ & $5-25$ & $\begin{array}{c}4-16 \\
9,5\end{array}$ & $\begin{array}{l}\text { Tidak dilakukan } \\
\text { Tidak dilakukan }\end{array}$ \\
\hline
\end{tabular}




\section{SRIWIJAYA \\ JOURNAL OF-OPHTHALMOLOGY}

धज्ञा

11,0

1 month after surgery

- Mean \pm Standar Deviasi
$11,5 \pm 4,48$
$9,29 \pm 2,85$
$11,2 \pm 2,32$

- Range

- Median

$5-23$

$5-16$

$8-20$

11,0

9,0

10,0

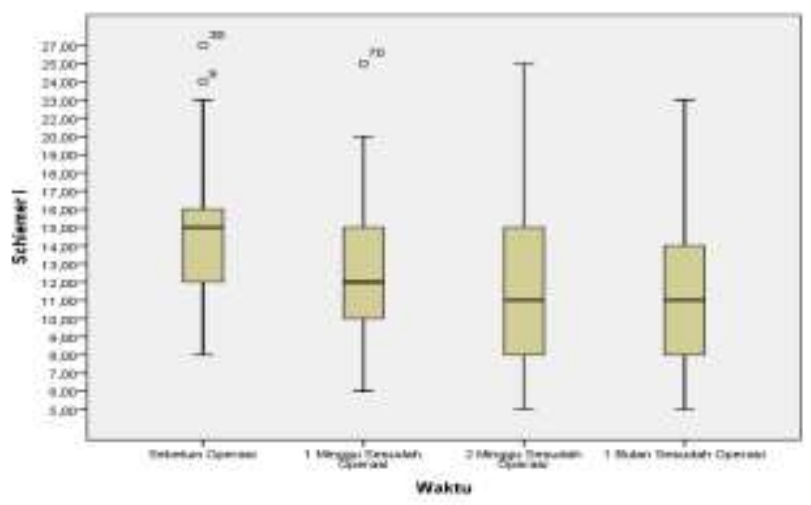

Figure 1. Schirmer I Value Chart Before and After Surgery

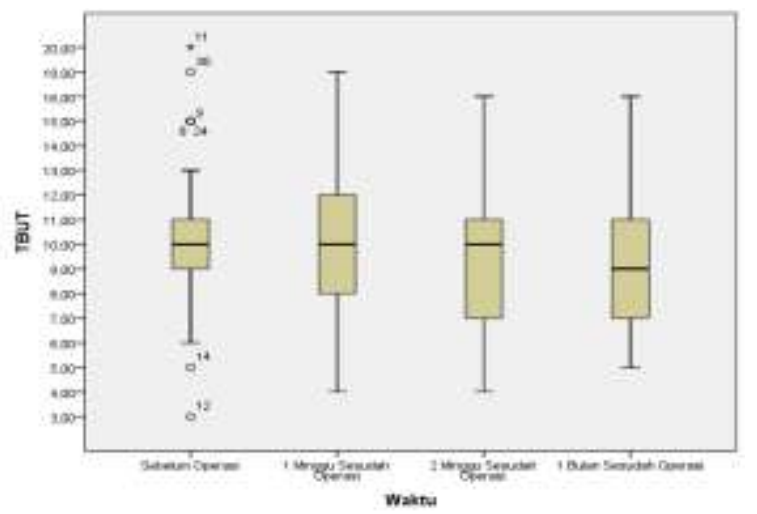

Figure 2. TBUT Graph Before and After Surgery

In this study, there were 15 post-operative cataract patients with abnormal Schirmer I values (37.5\%) and 38 abnormal TBUT values (95\%). 
JOURNALOFOPHTHALMOLOGY

GSO

Table 5 Schirmer I and TBUT Conformity Tests or Accuracy Based on Normal Values

\begin{tabular}{|c|c|c|c|c|}
\hline \multicolumn{2}{|c|}{} & \multicolumn{2}{c|}{ TBUT } & Total \\
\cline { 2 - 5 } \multicolumn{2}{|c|}{} & Abnormal & Normal & \\
\hline \multirow{3}{*}{ Schirmer I } & Abnormal & $15^{\mathrm{a}}$ & $0^{\mathrm{b}}$ & 15 \\
\cline { 2 - 5 } & & & & 25 \\
\hline & Normal & $23^{\mathrm{c}}$ & $2^{\mathrm{d}}$ & 40 \\
\hline \multicolumn{2}{|c|}{ Total } & 38 & 2 & \\
\hline
\end{tabular}

Based on table 4.5, the accuracy of Schirmer I and TBUT is 0.425 with a sensitivity of 39.5 $\% \%, 100 \%$ specificity, $100 \%$ positive predictive value (PPV) and $8 \%$ negative predictive value (NPV). The accuracy of the Schirmer I and TBUT examination in the eye Post operative cataract patients are 0.425 which means the degree of appropriateness of measurement (reliability) is not good.

Table 6 Conformance Test or Schirmer I and TBUT Accuracy based on Schirmer I Cut Off Points

\begin{tabular}{|c|c|c|c|c|}
\hline \multicolumn{2}{|c|}{ Examination } & \multicolumn{2}{c|}{ TBUT } & Total \\
\cline { 2 - 4 } \multicolumn{2}{|c|}{} & Abnormal & Normal & \\
\hline \multirow{3}{*}{ Schirmer I } & Abnormal & $37^{\mathrm{a}}$ & $0^{\mathrm{b}}$ & 37 \\
\cline { 2 - 5 } & Normal & $1^{\mathrm{c}}$ & $2^{\mathrm{d}}$ & 3 \\
\hline & & 38 & 2 & 40 \\
\hline
\end{tabular}

Based on table 4.6, the Schirmer I and TBUT examination above has a sensitivity of $97.4 \%$, specificity 100\%, positive predictive value (PPV) 100\%, negative predictive value (NPV) $66.7 \%$, positive Likelihood ratio $\infty$ and negative Likelihood ratio 0.026 . The accuracy of the Schirmer Idan TBUT examination based on the Schirmer I cut point in the eyes of postoperative cataract patients is 0.975 which means the degree of appropriateness of measurement (reliability) is very good 
Table 7 Conformance Tests or Schirmer I and TBUT Accuracy based on TBUT Intersection

\begin{tabular}{|c|c|c|c|c|}
\hline \multicolumn{2}{|c|}{ Examination } & \multicolumn{2}{c|}{ TBUT } & Total \\
\cline { 3 - 5 } \multicolumn{2}{|c|}{} & Abnormal & Normal & \\
\hline \multirow{3}{*}{ Schirmer I } & Abnormal & $14^{\mathrm{a}}$ & $8^{\mathrm{b}}$ & 22 \\
\cline { 2 - 5 } & Normal & $1^{\mathrm{c}}$ & $17^{\mathrm{d}}$ & 18 \\
\hline & & 15 & 25 & 40 \\
\hline \multicolumn{2}{|c|}{ Total } & & & \\
\hline
\end{tabular}

Based on table 4.7, the Schirmer I and TBUT examination has a sensitivity of 93.3\%, specificity 68\%, positive predictive value (PPV) 63.6\%, negative predictive value (NPV) 94.4\%, positive Likelihood ratio 2.915 and negative Likelihood ratio 0.099 . The accuracy of the Schirmer I and TBUT examination based on the TBUT cut point in the eyes of postoperative cataract patients is 0.775 which means the degree of appropriateness of measurement (reliability) is good.

\section{Discussion}

In this study, the average age of cataract patients was approximately 58 years with an age range of 43-70 years and the majority of patients aged over 60 years (50\%). The results of this study are slightly lower than the data from the research results of Chang et al. in China which reported the average age of cataract patients approximately 61 years. Also with the research of Usha et al. in India where the average age of cataract patients was found to be around 60 years. 32,33

In this study, the proportion of cataract patients with male sex compared to women was not much different (4: 5). The results of this study are not much different from the Aminatul study in 2016 in which the number of cataract patients in this study were more women than men (men vs women $=4: 5$ ). The results of this study were also supported by research conducted by Chang et al. in China in 2013 where the sex ratio in cataract patients was not much different (male vs female $=7$ vs 8 ). In general, it is said that men have a greater risk of developing cataracts than women because men do more outdoor activities which are associated with a lot of ultraviolet light exposure, especially in the tropics with high sun exposure intensity. However, other studies conducted in various countries get different results regarding gender 


\section{SRIWIJAYA JOURNALOF OPHTHALMOLOGY}

ध्रण0

predilection in cataract patients. Research in the United States found that a significant number of women suffer from cataracts than men.

The highest level of education of cataract patients in this study was bachelor, the level of education can be related to the speed and awareness of someone to obtain health services where patients with higher education levels usually seek health services more quickly, so that more cataracts are found. While the most work of cataract patients are retirees. Research results in India found $90 \%$ of patients with cataracts work in agriculture. Some researchers attribute the work to the length of time the patient performs outdoor activities which are then connected with the length of exposure to ultraviolet light experienced. The longer the outdoor activity will cause the greater exposure to ultraviolet light obtained. However, more retirees found in this study may be age-related, where ordinary retired patients are over 60 years old and are increasingly at risk of developing cataracts.

In this study 40 patients' eye samples were collected after cataract surgery using phacoemulsification technique, then TBUT and Schirme rI examinations were the most frequently performed objective clinical examinations and were recommended to diagnose dry eye syndrome. In this study OSDI scores were also assessed before and after 1 month of cataract surgery using phacoemulsification techniques to accurately determine complaints and symptoms of ocular irritation associated with dry eye syndrome. The study of Li et al., Compared the decline in the results of Schirmer and TBUT examination in 50 samples before and after cataract surgery for 3 months.

TBUT examination aims to assess the quality of tears ie the time it takes the surface of the eye (cornea) to lose cohesive surface wetting by measuring the time between the last complete blink with the formation of dry spots or tear film disruption. Under normal circumstances the tear layer has more than 10 seconds, whereas if it is less than 10 seconds indicates the tear layer is unstable. In this study, the mean TBUT value of cataract patients before surgery was approximately 10.5 seconds, which meant the average patient had a stable tear layer. The number of cataract patients with abnormal TBUT values was 34 patients (85\%). However, after cataract surgery the TBUT value decreased to approximately 9.29 seconds after 1 month of operation with the number of cataract patients with abnormal TBUT values increasing to 38 patients (95\%). This is in accordance with Kasetsuwan's research in 2010, found that TBUT decreased after phacoemulsification surgery by $68.4 \%$. While the study of Sahu, et al in 2015, obtained the same TBUT measurement time in pre operative and 1 month 


\section{SRIWIJAYA \\ JOURNALOF OPHTHALMOLOGY}

अ्ग्र

post operative phacoemulsification, but experienced abnormalities. on other dry eye syndrome examinations.

Schirmer I examination is an assessment of the secretory reflex function of the lacrimald gland and the basal secretion of the Krause and Wolfring glands. Wetting $<10 \mathrm{~mm}$ after 5 minutes is diagnostic for deficiency of the aquatic layer. In this study, the mean schirmer value of cataract patients before surgery was approximately $14.3 \mathrm{~mm}$, which means that the average patient had sufficient aquatic layers. The number of cataract patients with abnormal Schirmer I values was only 6 patients (15\%). But over time after cataract surgery the value of Schirmer I decreased to approximately $11.5 \mathrm{~mm}$ after 1 month of operation with the number of cataract patients with an abnormal Schirmer I value increasing to 15 patients (37.5\%). Li et al explained in his study that it was found a decrease of

In this study, there were 15 post-operative cataract patients with abnormal Schirmer I values (37.5\%) and 38 abnormal TBUT values (95\%). With diagnostic tests based on normal values, the sensitivity results are $39.5 \%$ and specificity is $100 \%$, this means that the ability of the abnormal Schirmer I value to detect abnormal TBUT values is only $39.5 \%$ while the ability of the normal Schirmer I value to detect normal TBUT values by $100 \%$. All patients with normal Schirmer I will have a normal TBUT value, whereas patients with an abnormal Schirmer I value are likely to be $39.5 \%$ who have an abnormal TBUT value. The accuracy value of Schirmer I and TBUT based on the normal value is 0.425 which means that the degree of appropriateness of the measurement (reliability) is not good.

\section{Conclusion}

The accuracy of the Schirmer I and TBUT examination in the eyes of postoperative cataract patients with phacoemulsification technique is 0.425 , which means the degree of appropriateness of measurement (reliability) is of poor value.

\section{References}

1. American Academy of Opthalmology. Basic and Clinical Science Course:120.Section 2-Fundamental and Principles, American Academy of Ophthalmology.2014-2015

2. American Academy of Opthalmology. Basic and Clinical Science Course:120.Section 6-Orbit, Eyelid and Lacrimal System,American Academy of Ophthalmology.2014-2015 


\section{SRIWIJAYA \\ JOURNALOF OPHTHALMOLOGY}

अग्र०

3. American Academy of Opthalmology. Basic and Clinical Science Course:120.Section 8-External Disease and Cornea,American Academy of Ophthalmology.2014-2015

4. Lemp, M.A. Tear Film Evaluation. In : Krachmer, Mannis, Holland, editors. Cornea: Fundamentals, Diagnosis and Management. $3^{\text {rd }}$.Ed.Elsevier-Mosby.p:79-85.2011

5. Dry Eye Workshop. 2007. The Definition and Classification of Dry Eye Disease :Report of the Definition and Classification Subcommittee of the International DEWS. The Ocular Surface 5(2): 75-92.

6. Stamper, L Robert, Marc F Lieberman, Michael V Drake. Becker-Shaffer's. 2009. Diagnosis and Theraphy of The Dry Eyes. Chapter 1. Mosby. Elsevier.

7. Li XM, Hu L, Hu J, and Wang W. 2007. Investigation of Dry Eye Disease and Analysis of the Pathogenic Factors in Patients After Cataract Surgery.Cornea. 26(Suppl.1): S16-S20

8. Ram J, Sharma A, Pandav SS, Gupta A, Bambery P.2016. Cataract Surgery in Patients with dry eyes. J. Cataract Refract surgery.Aug;24(8):1119-24

9. Cho YK, Man Soo Kim, Dry Eye After Cataract Surgery and Associated Intraoperative Risk Factors. Korean J Ophtalmol.2009 June; 23(2):65-73

10. Cetinkaya, et al.2015. The course of Dry Eye After Phacoemulsification Surgery.BMC Ophtalmology.

11. Sahu, Das, Biakthangi. 2015. Dry Eye Following Phacoemulsification Surgery and its Relation to Assosiated Intraoperative Risk Factors. Middle East Afr J Ophtalmol 22(40):472-477

12. Kamla Dodia,Siddhesh Bapat,R.K. Chudasama, 2013. Dry Eye Risk Factors after Phacoemulsification Cataract Surgery at a Secondary Care Hospital. Indian Journal Opthtalmol2(4):242-245

13. Messmer, E.M. 2015. The Pathophysiology, Diagnosis, and Treatment of Dry Eye Disease. DeutschesArzteblatt International 112(5): 71-81.

14. Phadatare, S.P et al. 2015. A Comprehensive Review on Dry Eye Disease: Diagnosis, Medical Management,Recent Development, and Future Challenges. (Online) (http://dx.doi.org/10.1155/2015/704946, diakses pada 1 Agustus 2017).

15. Miyake K, Yokoi N.2016. Influence on Ocular Surface After Cataract Surgery and Effect of Topical Diquafosol on Postoperative Dry Eye: a multicenter prospective randomized study. (Online)

(https://doi.org/10.2147/OPTH.S129178, diakses 9 Februari 2017). 


\section{SRIWIJAYA \\ JOURNALOFOPHTHALMOLOGY}

अग्र०

16. Manaviat, M.R. et al. 2008. Prevalence of Dry Eye Syndrome. BMC Opthalmology 8:10.

17. Ankita S, Samir G, Sunita M. 2011.A Review Recent Advances in Dry Eye: Pathogenesis and Management. Oman Journal of Ophtalmology vol 4 no.2

18. Pallikaris, Ioannis, et al. 2010. Ocular Rigidity. Expert Review of Ophthalmology. 2010;5(3): $343-351$.

19. Leonard A Levin, et al.2010. Adler's Physiology Of The Eye, eleventh edition, Philadelphia, Elsevier

20. Lang, Gerhard. Ophthalmology. 2005.Second Edition. Thieme. Germany: 2007.James Bruce, et all : Ophthalmology Investigation and Examination Techniques , British, Elsevier

21. Meek KM, Tuft SJ, Huang Y et al. 2005. Changes in Collagen Orientation and Distribution in keratoconus corneas. Invest. Ophthalmol. Vis. Sci. 46(6), 1948-1956.

22. American Academy of Opthalmology. Basic and Clinical Science Course:120.Section 11-Lens and Cataract,American Academy of Ophthalmology.2014-2015

23. Chang D., Zhang X., Rong S., Sha Q., Liu P., Han T., dan Pan H. 2013. Serum Oxidative Enzyme Level and Oxidative Stress Product in Age-Related Cataract Patients. Oxidative Medicine and Cellular Longevity, 1-7. 2013

24. Aminatul Fitria. Hubungan Umur, Sikap, Pengetahuan, Biaya terhadap Tindakan untuk Melakukan Operasi Katarak. Jurnal Berkala Epidemiologi,Vol. 4 No. 2, Mei 2016: 176187

25. Valero M.P., Fletcher A.E., Stavola B.L., dan Alepúz V.C. 2007. Years of Sunlight Exposure and Cataract: a Case-Control Study in a Mediterranean population. BMC Ophthalmology, 7: 1-8.

26. Katoh N., Jonasson F., Sasaki H., Kojima M., Ono M., Takahashi N., dan Sasaki K. 2001. Cortical lens Opacification in Iceland. Acta Ophthalmol Scand, 79: 154159.

27. Leske M.C., Wu S.Y., dan Nemesure B. 2002.Risk Factors for Incidence Nuclear Opacities. Ophthalmology, 109: 1303-1308.

28. Venincasa, Anat Galor, Feuer, et al. 2013. Long-Tem Effects of Cataract Surgery on Tear Film Parameters. The Scientific World Journal Vol 2013.Article ID 643764,(Online)(http://dx.doi.org/10.1155/2013/643764, diakses tanggal 21 November 2014) 


\section{JOURNAL OF OPHTHALMOLOGY}

ध्ग्20

29. Roberts CW, Elie ER. 2007. Dry Eye Symptoms Following Cataract Surgery. Insight 2007;32(1):14-23.

30. Snirivasan R, Agarwal V, Suchismitha $\mathrm{T}$, and Kavitha S, Dry Eye AfterPhacoemulsification. AIOC Proceedings.2008

31. You R, ZhonghuaYan.2017. Comparison of two kinds of Artificial Tears on the Dry Eye After Phacoemulsification.Chin J Ophtalmol;53:445-450.

32. Kasetsuwan N, et al. 2013.Incidence and Pattern of Dry Eye After Cataract Surgery. Plos One.44:230-235.

33. Kohli P, et al. 2019. Changes in Ocular Surface status After Phacoemulsification in Patients with Senile Cataract.International Ophtalmology.Vol 39;1345-1353.

34. Suryani, dkk.2019. Perbandingan Dry Eye Setelah Operasi Fakoemulsifikasi antara Letak Insisi Temporal dengan Letak Insisi Superior. JST Kesehatan.Vol 9;93-101

35. Xue W, et al. 2019. Long-term impact Dry Eye Symptoms on Vision-Related Quality of Life After Phacoemulsification Surgery. International Ophtalmology. Vol.39;419-429

36. Yao K, et al. 2015. Efficacy of $1 \%$ Carboxymethylcellulosa Sodium for Treating Dry Eye After Phacoemulsification: Result from Multicenter, Open-Label, Randomized, Controlled Study.BMC Ophtalmology.China;15:28. 